\title{
ХІРУРГІЧНА ТАКТИКА ПРИ ЛІКУВАННІ НЕКРОТИЧНОГО ПАНКРЕАТИТУ
}

\author{
В. Г. Ярешко, А. І. Марусій \\ Запорізька медична академія післядипломної освіти \\ SURGICAL TACTICS IN THE TREATMENT OF NECROTIC PANCREATITIS
}

\author{
V. G. Yareshko, A. I. Marusiy \\ Zaporizhzhya Medical Academy of Postgraduate Education
}

\begin{abstract}
Реферат
Вступ. Некротичний панкреатит (НП) є одним з найтяжчих захворювань органів черевної порожнини, характеризується порушенням перфузії підшлункової залози (ПЗ) різного ступеня, що потребує диференційованого підходу до хірургічного лікування пацієнтів.

Матеріали і методи. Проаналізовані результати лікування 66 хворих, яким виконували лапаротомні втручання 3 приводу НП 3 розробкою власних підходів на підставі оцінки життєздатності ПЗ. Розроблені показання до резекції ПЗ, методи дренування гнійних вогнищ, способи завершення операції.

Результати. Встановлено, що при некрозі понад 50\% об'єму ПЗ і сепсисі потрібне її обов'язкове видалення як першоджерела інфекції, з широким дренуванням заочеревинного простору та завершенням операції для подальшої «планової» релапаротомії. Обговорення. Навіть у теперішній час, коли можлива об’єктивна оцінка ступеню перфузії ПЗ та об'єму некрозу парапанкреатичної клітковини за даними КТ і шкал оцінки септичного стану, не визначені питання щодо прямих втручань на ПЗ, методів завершення операції.

Висновки. Зменшення летальності після відкритих операцій з приводу НП можливе за умови ранньої діагностики захворювання, до появи необоротних некротичних змін ПЗ за даними променевих методів дослідження (УЗД, КТ) та оптимізації обсягу оперативного втручання.

Ключові слова: некротичний панкреатит; резекція підшлункової залози; дренування заочеревинного простору.

Abstract

Introduction. Necrotic pancreatitis is one of the severest abdominal diseases, which is characterized by the pancreatic perfusion disorder of different degree and demands differentiated approach for the patients surgical treatment.

Materials and methods. Results of treatment of 66 patients, to whom the laparotomy interventions for necrotic pancreatitis were performed, using elaborated own approaches, based on the pancreatic tissue vitality estimation, were analyzed. Indications for pancreatic resection, methods of purulent accumulations drainage and the operative procedures concluding were elaborated.

Results. There was established, that in necrosis over $50 \%$ of pancreatic volume and sepsis it is mandatory to perform total pancreatectomy to remove the infection origin, using wide retroperitoneal drainage and to conclude the operation to perform further "planned" relaparotomy. Discussion. Even in modern conditions, when objective estimation of pancreatic perfusion and the necrotic parapancreatic cellular tissue volume are possible in accordance to CT data and the septic state estimation scales, the issues of direct pancreatic resection application and methods of the operations conclusion still are not elaborated.

Conclusion. It is possible to reduce lethality after open operations for necrotic pancreatitis if early diagnosis is accomplished before irreversible pancreatic necrotic changes occur in accordance to radiological investigations (USG, CT) data and due to the operative intervention volume optimization.

Keywords: necrotic pancreatitis; pancreatic resection; retroperitoneal space drainage.
\end{abstract}

Некротичний панкреатит (НП) $€$ одним 3 найтяжчих захворювань органів черевної порожнини, характеризується порушенням перфузії ПЗ різного ступеня, утворенням локальних або поширених гнійних вогнищ, виникненням тяжкого панкреатогенного перитоніту, синдрому системної запальної відповіді (ССЗВ), сепсису, септичного шоку $[1,2]$. Нерідко сепсис і системна дисфункція випереджають фатальні зміни при НП і є безпосередньою причиною смерті. Найбільш часто некротичні зміни відбуваються в лівій половині ПЗ [3]. При цьому ПЗ є первинним джерелом сепсису, глибокі некротичні зміни в ній необоротні, а iï несвоєчасне видалення під час лапаротомії сприяє поширенню гнійного процесу в черевній порожнині, критичному порушенню основних життезабезпечувальних систем організму [4]. Тому недооцінка динаміки некротичних процесів в ПЗ, заочеревинному просторі, черевній порожнині, а головне- відсутність дій хірурга на випередження спричиняють несвоєчасне виконання оперативного втручання, виникнення тяжких інтраабдомінальних ускладнень (прогресування перитоніту, ерозивної кровотечі, кишкової нориці тощо). Операції з приводу таких ускладнень, як правило, здійснюють за критичного стану хворо- го, вони супроводжуються надвисокою летальністю $[1,3]$. Тому під час лапаротомії актуальними $є$ питання оцінки життездатності ПЗ, локалізації та поширення гнійних вогнищ. Від цього залежить і метод завершення операції- здійснити бурсооментостомію, зашити лапаротомну рану, застосувати «планову» релапаротомію або активні методи дренування.

\section{МАТЕРІАЛИ I МЕТОДИ ДОСЛІДЖЕННЯ}

В спеціалізованій хірургічній клініці оперовані 134 хворих з приводу НП, у яких виконана 171 операція 3 використанням різних сучасних ме- 
тодів. Проаналізовані результати лікування 66 (49,3\%) хворих, яким виконані за показаннями 87 лапаротомних операцій. Лапаротомія, дренування постнекротичних абсцесів здійснені у 10 (15,1\%) хворих; лапаротомія, некрсеквестректомія, дренування панкреатичного абсцесу, сальникової сумки і черевної порожнини- у 26 (39,4\%); лапаротомія, лівобічна панкреатосеквестректомія, дренування флегмони заочеревинного простору- у 30 (45,5\%).

Комп'ютерну діагностику ускладнень та глибини структурних порушень ПЗ виконували за допомогою томографа фірми Siemens (Німеччина) 3 внутрішньовенним підсиленням 3 використанням контрастної речовини «Омнімак 350».

Показаннями до виконання лапаротомної операції з приводу НП були в основному поширені вогнища гнійної панкреатичної інфекціiі, КТ індекс тяжкості BalthazarBredley (сума балів КТ індексу тяжкості та площа некрозу ПЗ): від 0 до 3 балів відповідав категорії А, B, C, некроз до 30\% площі П3; від 4 до 6 балів- категорії C, D, некроз від 30 до 50\% площі П3; від 7 до 10 балів- категорії D, Е, некроз більше 50\% площі П3. Результати хірургічного лікування оцінювали за глибиною некротичних змін ПЗ, поширенням гнійних вогнищ та способом операції.

У 10 (15,1\%) хворих, в тому числі у 4- за КТ індексу А, В, С, у 6- C, $\mathrm{D}$, здійснено лапаротомію, дренування панкреатичних абсцесів; у 26
(39,4\%) хворих, в тому числі 9- за КТ індексу A, B, C та 17- C, D, виконані лапаротомія, некрсеквестректомія, дренування гнійних вогнищ сальникової сумки і черевної порожнини. Умовно ці 36 хворих включені у першу групу, у них не виконували пряме втручання на ПЗ. У 30 (45,5\%) хворих (друга група), в тому числі 9- за КТ індексу C, D та 21- D, E, виконані лівобічна панкреатосеквестрнекректомія, спленектомія, дренування заочеревинного простору.

\section{РЕЗУЛЬТАТИ}

Результати хірургічного лікування НП залежно від КТ індексу тяжкості Balthazar-Bredley наведені у таблиці.

В першій групі після дренування постнекротичних абсцесів всі пацієнти живі, повторних операцій не було. Після дренування абсцесу та некрсеквестректомії повторні операції виконані у 6 хворих з приводу прогресування некрозу ПЗ та утворення нових абсцесів, в тому числі дренування панкреатичних абсцесів- у 4, дистальна резекція П3, секвестрнекректомія- у 2. Операції виконували у середньому через (10 \pm 2 ) доби після першого втручання. Померли 2 хворих на 20-ту та 25ту добу після резекціі П3, секвестрнекректомії внаслідок прогресування сепсису і тяжкої поліорганної недостатності. Основними ускладненнями в першій групі були арозивна кровотеча- в 1 хворого, утворення панкреатичної нориці- у 3, нагноєння операційної рани- у 10. Всі ці ускладнення лікували консервативними засобами. Тривалість лікування хворого у стаціонарі у середньому (20 \pm 3$)$ доби.

В другій групі після лівобічної панкреатосеквестректомії, спленектомії, дренування заочеревинного простору і черевної порожнини повторні операції виконані у 15 (50\%) хворих, в тому числі планова релапаротомія- у 9, санаційна релапаротомія тричі з інтервалом (2 \pm 1) добу- у 2, релапаротомія двічі- у 3, по одному разу- у 4. За терміновими показаннями у 2 хворих релапаротомія виконана з приводу млявого перебігу перитоніту, виникнення гострої непрохідності кишечнику, арозивної кровотечі. Після операції померли 8 (26,7\%) хворих, що вірогідно перевищувало показник у першій групі ( $<<0,05)$. Причиною смерті були прогресування сепсису та тяжкої поліорганної недостатності. Ускладнення виникли у 19 (63,3\%) хворих, в тому числі у 4- товстокишкова нориця, в 1- нориця дванадцятипалої кишки, у 2- прогресування перитоніту та гострої непрохідності кишечнику, у 10- нагноєння операційної рани, у 2- арозивна кровотеча. У 13 (43,3\%) хворих після резекції ПЗ утворилася панкреатична нориця, що функціонувала впродовж 14 діб та самостійно закрилася після консервативної терапії. Тривалість лікування хворого у стаціонарі у середньому (29 \pm 3$)$ доби ( $<0,05)$.

Аналізуючи результати хірургічного лікування хворих $з$ приво-

Результати хірургічного лікування НП

\begin{tabular}{|c|c|c|c|c|c|c|c|c|c|c|c|}
\hline \multirow{4}{*}{ Операція } & \multirow{4}{*}{$\begin{array}{c}\text { Кількість } \\
\text { хворих }\end{array}$} & \multicolumn{6}{|c|}{ КТ індекс } & \multirow{3}{*}{\multicolumn{2}{|c|}{$\begin{array}{c}\text { Кількість } \\
\text { повторних операцій } \\
\text { (планова санація) }\end{array}$}} & \multirow{3}{*}{\multicolumn{2}{|c|}{ Померли }} \\
\hline & & \multicolumn{2}{|c|}{$A, B, C$} & \multicolumn{2}{|c|}{$C, D$} & \multicolumn{2}{|c|}{$\mathrm{D}, \mathrm{E}$} & & & & \\
\hline & & 2 万丂 & 0 & 25 & 0 & 25 & \% & & & & \\
\hline & & dol. & 10 & aoc. & $\%$ & aoc. & $\%$ & абс. & $\%$ & абс. & $\%$ \\
\hline $\begin{array}{l}\text { Лапаротомія. } \\
\text { Дренування } \\
\text { постнекротичних абсцесів }\end{array}$ & 10 & 4 & 40 & 6 & 60 & - & - & - & - & - & - \\
\hline $\begin{array}{l}\text { Лапаротомія. } \\
\text { Некрсеквестректомія. } \\
\text { Дренування } \\
\text { панкреатичного абсцесу, } \\
\text { сальникової сумки } \\
\text { і черевної порожнини } \\
\end{array}$ & 26 & 9 & 34,6 & 17 & 65,4 & - & & 6 & 23,1 & 2 & 7,7 \\
\hline Разом & 36 & 13 & 36,1 & 23 & 63,9 & - & & 6 & 16,7 & 2 & 5,6 \\
\hline $\begin{array}{l}\text { Лапаротомія. Лівобічна } \\
\text { панкреатосеквестректомія, } \\
\text { спленектомія. } \\
\text { Дренування } \\
\text { заочеревинного простору і } \\
\text { черевної порожнини }\end{array}$ & 30 & - & & 9 & 30 & 21 & $70^{*}$ & 15 & 50 & 8 & 26,7 \\
\hline Загалом ... & 66 & 13 & 19,7 & 32 & 48,5 & 21 & 31,8 & 21 & 31,8 & 10 & 15,2 \\
\hline
\end{tabular}


ду НП, ми встановили, що вмирали тільки хворі, яким виконували резекцію ПЗ, як після першої, так і повторних операцій.

\section{ОБГОВОРЕННЯ}

Навіть у теперішній час, коли є можливість об'єктивної оцінки ступеня перфузії ПЗ та об'єму некрозу парапанкреатичної клітковини за даними КТ і шкал оцінки септичного стану, питання прямого втручання на ПЗ та методів завершення операції не визначені [4- 7]. 3 нашої точки зору, при некрозі понад 50\% об'єму П3 і виникненні сепсису слід обов'язково видаляти ПЗ як першоджерело інфекції з широким дренуванням заочеревинного простору та завершенням операції для подальшої «планової» релапаротомії. В нашому дослідженні у другій групі після резекції ПЗ у 15 (50\%) хворих виконували «планову» релапаротомію. В 1-й групі при прогресуванні гнійно-некротичного процесу в ПЗ та заочеревинному просторі повторні операції виконані у 6 (16,7\%) хворих. Разом релапаротомія здійснена у 21 (31,8\%) хворого.

Як правило, осумковані та дифузні гнійні вогнища локалізувалися в різних відділах заочеревинного простору, аж до тотального ураження. Запропоновані способи дренування передбачали в основному локальне дренування гнійних вогнищ або використання перитонеального лаважу (див. рисунок).

Недоліком таких методик $є$ «пасивність» і неадекватність видалення некротизованих тканин з заочеревинного простору, висока ймовірність подальшого поширення гнійного процесу по анатомічних відді-
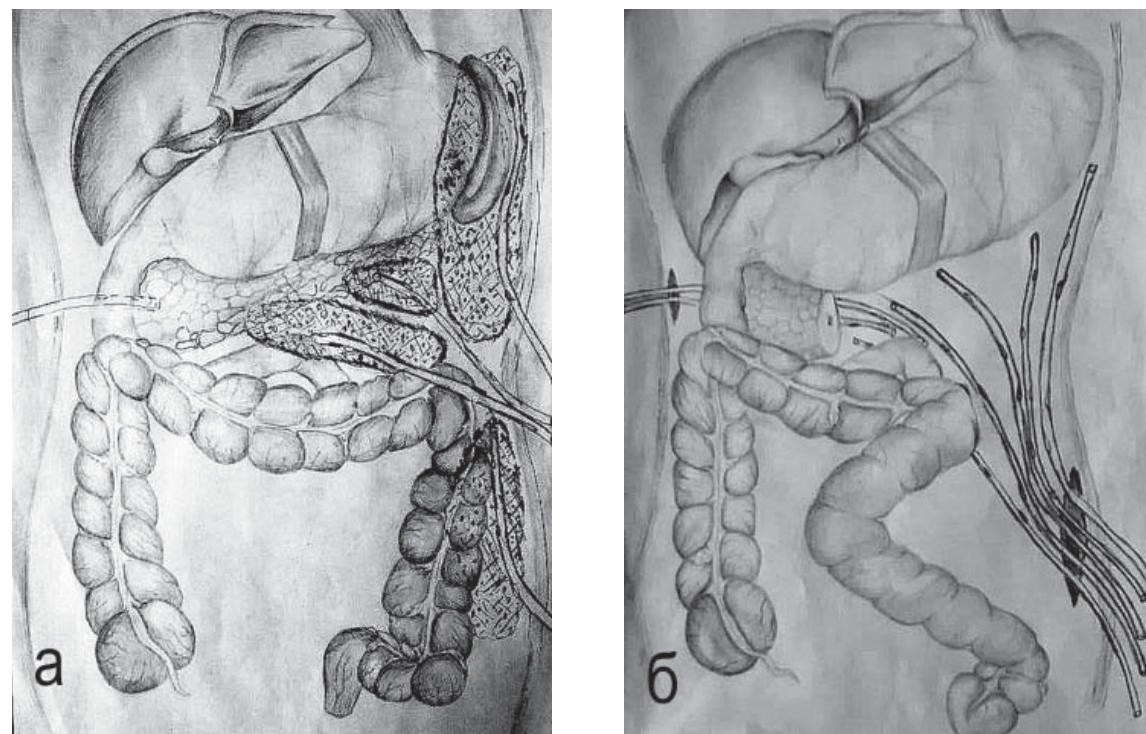

Схема дренування гнійних вогнищ при НП.

а- загальноприйняті точки встановлення дренажів в порожнину кожного абсцесу; б- мобілізація перегородок між абсцесами з широким дренуванням заочеревинного простору, видаленням дистальної частини некротизованої ПЗ з парапанкреатичною клітковиною.

лах, підтримання персистуючої інфекції та сепсису.

В запропонованій нами методиці ці недоліки усунуті завдяки широкому дренуванню заочеревинного простору від діафрагми до порожнини малого таза, мобілізації брижі тонкого й товстого кишечнику, роз'єднанню перегородок між абсцесами, некректомії в межах неуражених тканин та обов'язковому видаленню лівої половини ПЗ в стадії D, E. Це сприяло значному підвищенню ефективності лаважу і зовнішнього дренування єдиної гнійної порожнини, попередженню прогресування та утворення нових залишкових гнійних вогнищ, зменшенню частоти виконання «планової» санаційної лапаротомії.

\section{ВИСНОВКИ}

1. Зменшення летальності після відкритих операцій 3 приводу НП можливе за умови ранньої діагностики захворювання, до появи необоротних некротичних змін ПЗ за даними променевих методів дослідження (УЗД, КТ), оптимізації обсягу оперативного втручання.

2. Висока летальність (більше 25\%) може бути виправданою лише за умови глибокого гнійно-некротичного ураження ПЗ (КТ індекс тяжкості Balthazar\&Bradley D, E) та заочеревинного простору, виникнення сепсису та тяжкої органної дисфункції.

\section{REFERENCES}

1. Petrov MS, Shanbhag S, Chakraborty M, Phillips $P$, Windsor JA. Organ failure and infection of pancreatic necrosis as determinants of mortality in patients with acute pancreatitis. Gastroenterology. 2010;139:813-20. doi: 10.1053/j.gastro.2010.06.010. PMID: 20540942

2. Banks PA, Freeman ML. Practice Parameters Committee of the American College of Gastroenterology. Practice guidelines in acute pancreatitis. Am J Gastroenterol. 2006;101:2379-400. doi:10.1111/ j.1572-0241.2006.00856.x

3. Reddy MS, Singh S, Singh R, Singh K, Singh G. Morphological and functional outcome after pancreatic necrosectomy and lesser sac lavage for necrotizing pancreatitis. Ind J Gastroenterol. 2007;26:21720.

4. van Santvoort HC, Bakker OJ, Bollen TL, Besselink MG, Ahmed Ali U, Schrijver AM, et al. A conservative and minimally invasive ap- proach to necrotizing pancreatitis improves outcome. Gastroenterology. 2011;141:1254-63. doi: 10.1053/j.gastro.2011.06.073

5. Freeman M, Werner J, van Santvoort HC, Baron TH, Besselink MG, Windsor JA, et al. Interventions for necrotizing pancreatitis summary of a multidisciplinary consensus conference. Pancreas. 2013;41(8):1176-94. doi: 10.1097/MPA.0b013e318269c660

6. Working group IAP/APA Acute Pancreatitis Guidelines. IAP/APA evidence-based guidelines for the management of acute pancreatitis. Pancreatology. 2013;13:1-15. doi: 10.1016/j.pan.2013.07.063

7. Terner S, Baillie J, DeWitt J, Vege SS. American College of Gastroenterology Guideline: Management of acute pancreatitis. Am J Gastroenterol. 2013;108(9):1-16. doi: 10.1038/ajg.2013.218. 